\title{
EFFECT OF PERIOD OF CULTIVATION ON THE ABUNDANCE AND DISTRIBUTION OF WEED SEEDS IN THE SOIL PROFILE
}

\author{
Z. MAVUNGANIDZE ${ }^{1 *}$ - G.S. MAKUNDE ${ }^{2}-$ A.B. MASHINGAIDZE ${ }^{2}-$ O.A. CHIVINGE $^{2}-$ \\ C. RICHES ${ }^{3}-J$. ELLIS-JONES ${ }^{3}$ \\ ${ }^{1}$ Crop Science Department, University of Zimbabwe, P.O. Box MP 167, Mt Pleasant, Harare, \\ Zimbabwe \\ ${ }^{2}$ Natural Resources Institute, University of Greenwich Clatham Maritime, Kent ME4 4TB, UK \\ ${ }^{3}$ Silsoe Research Institute, Wrest Park, Silsoe, Berdford, MK45 4HS, UK \\ *Corresponding author \\ e-mail: ziramavunganidze@yahoo.co.uk
}

(Received $1^{\text {st }}$ October 2006 ; accepted $6^{\text {th }}$ July 2009)

\begin{abstract}
An experiment was laid down in the greenhouse to determine the distribution of weed seeds at different soil depths and period of cultivation on the distribution of weed seed bank in the soil profile in Muzarabani. Soil samples from different depth levels (0-10, 10.1-20, 20.1-30 cm) were collected soon after harvesting from three different sites namely Gutsa, Mufudzi and Muringazuva of Muzarabani district. The soil samples were put in trays in the greenhouse and watered after every two days to field capacity. Weed seedlings were identified, counted, recorded and discarded for a period of 3 months. Soil samples were disturbed every week to allow more germination of dormant weeds. Depth $(\mathrm{P}=0.000)$ and site $(\mathrm{P}=0.005)$ had highly significant effects on the total number of weeds that emerged from the soil samples. The $0-10 \mathrm{~cm}$ of the soil had the highest weed seedlings that emerged. There was an equal weed seed distribution in the $10-20 \mathrm{~cm}$ and the $20-30 \mathrm{~cm}$ of the soil. Gutsa had the largest seed bank and there was no significant difference in seed bank size between Mufudzi and Muringazuva. Some weed species were site specific, Senna obtusifolia was only found in Muringazuva and absent in other sites. Eleusine indica was found in Mufudzi and was absent in other sites.
\end{abstract}

Keywords: weed, soil, greenhouse, germination

\section{Introduction}

Weeds are a menace in agricultural systems the world-over and their management has squandered enormous human and financial capital since the beginning of plant domestication. Extensive research has been done to address this problem and various management packages have been formulated (Clements, Weise and Swanton, 1994). On the contrary, weeds have continued to proliferate and to perfect their survival mechanisms.

Most of the annual weeds ensure their survival through production of large numbers of seed within a short time which can be dispersed through contaminated crop seeds, animal feed, manure and water or transported to distant places on animal hair, fur or wool as well as cultivation and harvesting machinery (Akobundu, 1987). Some of the dispersed weed seeds end up on the soil surface or in the soil. Therefore, the success of weeds is enhanced by the soil seed reservoir that is the major source of weed infestation in most tilled agricultural soils (Altieri and Liebman, 1988). The numbers, types and distribution of weed seeds in their reservoir are determined by the fields location and cropping history, edaphic characteristics such as moisture holding capacity and past 
weed control practises (Janiya and Moody, 1989) as well as tillage, land preparation methods and weed seed dormancy (Zimdahl, Moody, Lubigan and Castin, 1988).

Weeds compete for soil mineral nutrients, water and light resulting in 'leggy' cotton, poor plant development, delayed maturity and reduced yields if the weeds are not removed by up to four hoe weedings per season (Cotton Handbook, 1985). Two hoe weedings per season are carried out in each maize field in Muzarabani in order to get a reasonable yield. Late weeds interfere with picking, and weed seeds shed and trash from cotton leaves on cotton lint may result in downgrading (Cotton Handbook, 1985).

Because of the persistence of seeds in the seed-bank, weeds are a major problem in Muzarabani and there have been reports of stagnant or reduced yields despite the use of superior varieties and improved farming methods. Average cotton yields are reported to be around 1 tonne per ha while maize yields are about 0,7 tonnes per ha (Department of Agriculture Technical Extension Services, 1999).

Since one of the major factors affecting annual weed population stability is the large and potentially transient seed-bank, it means seed banks are of ecological and evolutionary importance in the dynamics of weed population and communities. Barralis and Chadoeuf (1987), have found that with the exception of weeds with large seeds, the seed-bank is a better indicator of the long-term influence of agronomic practices on weeds than the above ground vegetation. Knowledge on weed seed distribution in different soil layers makes it possible to develop appropriate approaches and techniques for tillage and long-term weed management. Hence for sustainable cropping, it is important to acquire knowledge on the biological and ecological behaviour of weeds to develop guidelines for environmentally sound weed control (Altieri, 1998; Zimdahll, 1998). In this respect, knowledge of the weed seed-bank is very important because it provides evidence of past field management and may allow forecasts on future weed problems (Wilson et al., 1985 and Forcella, 1992).

\section{Objectives}

The objectives of the study were to:

(a) determining the effect of soil depth and period of cultivation on the distribution of weed seedbank in soil profile in the lower Zambezi valley.

\section{Materials and Methods}

Three fields with different soil types (alluvial soils, sandy loam, cracking vertisols) and different periods of cultivation $(>20$ years, $>10$ years and $<5$ years) respectively were selected in lower Zambezi valley. A total of 10 randomly selected soil samples were collected from $0-10 \mathrm{~cm}, 10.1-20 \mathrm{~cm}$, and $20.1-30 \mathrm{~cm}$ depth of the soil profile in September 2000. The soil cores of the same depth were bulked together and passed through a $2 \mathrm{~mm}$ sieve to remove non-reproducing vegetation material and stones. The samples were spread in asbestos trays of $55 \mathrm{~cm} \times 30 \mathrm{~cm}$ which were thoroughly cleaned before soil samples were incubated to make sure that there was no contamination of soil samples with herbicides, since the trays have been used for various purposes before. Soil samples from each sampling position were randomly allocated to the asbestos trays to make a replicate. Soil samples in asbestos trays were watered after every two days to field capacity with distilled water. The weeds that germinated were identified by species, counted and discarded. The total number of weeds that emerged was considered 
as transient weed seed bank was expressed $\mathrm{m}^{-2}$. The soil samples were disturbed for three months to allow more germination of weed seeds in the soil. The total number of weeds that emerged was considered as transient weed seed-bank. The experiment was laid out as factorial in a randomised complete block design with three treatments replicated five times. The factors were the depth of soil samples with three levels $(0-10 \mathrm{~cm}, 10.1-20$ $\mathrm{cm}, 20.1-30 \mathrm{~cm}$ ) and site from which the soil samples were collected with three levels (Mufudzi, Gutsa and Muringazuva). Actual data were transformed using square root transformation before ANOVA to increase homogeneity of error variances. The statistical package used was Minitab version 5.1.

\section{Results}

\section{All weeds}

Site $(\mathrm{P}=0.005)$ and depth of soil sample $(\mathrm{P}=0.000)$ had highly significant effects on the number of all weeds that emerged from incubated soil samples. There was no interaction between site and depth of soil sample $(\mathrm{P}>0.05)$. Gutsa site had the highest number of weeds emerging from the collected soil samples (Table 1). Muringazuva and Mahwenda site had similar numbers of germinable weeds within their seed banks.

Table 1. Effect of site on the number of germinable weed seeds (square root transformed)

\begin{tabular}{|c|c|c|c|}
\hline \multicolumn{4}{|l|}{ Site } \\
\hline Gutsa & & & 9.46a (157.07) \\
\hline Mufudzi & & & $3.80 b(21.53)$ \\
\hline \multirow[t]{2}{*}{ Muringazuva } & & & $5.86 \mathrm{~b}(61.93)$ \\
\hline & Significance & S.E.D & L.S.D $D_{0.05}$ \\
\hline Effect of site & $\mathrm{P}=0.005$ & 1.61 & 3.28 \\
\hline Effect of depth & $\mathrm{P}=0.000$ & 1.61 & 3.28 \\
\hline Site $\mathrm{x}$ depth & NS & NS & NS \\
\hline
\end{tabular}

Highest number of weeds emerged from the $0-10 \mathrm{~cm}$ incubated soil samples (Fig 1.). The 10-20 cm and 20-30 cm depth levels had similar numbers of germinable weeds.

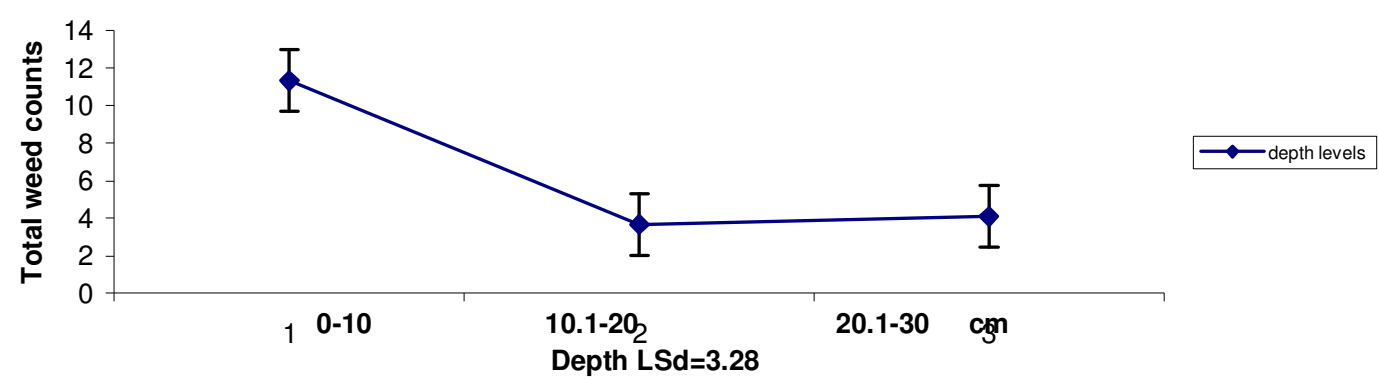

Figure 1. Efferct of depth on total weed emergence 


\section{Individual weeds}

\section{Portulaca oleracea}

Site $(\mathrm{P}>0.05)$ and depth $(\mathrm{P}>0.05)$ had no effect on the seed bank of Portulaca oleracea. There was no interaction between site and depth $(\mathrm{P}>0.05)$.

\section{Richardia scabra}

Site $(\mathrm{P}=0.000)$ and depth of soil sample $(\mathrm{P}=0.008)$ had highly significant effects on Richardia scabra emergence from incubated soil samples. There was a significant interaction between site and depth of soil sample $(\mathrm{P}=0.052)$. Ricardia scabra was more abundant in the soils at Gutsa site than at Mufudzi and Muringazuva. Richardia scabra was more abundant at 0-10 am depth than at 10-20 cm and 20-30 cm depth (Fig 2).

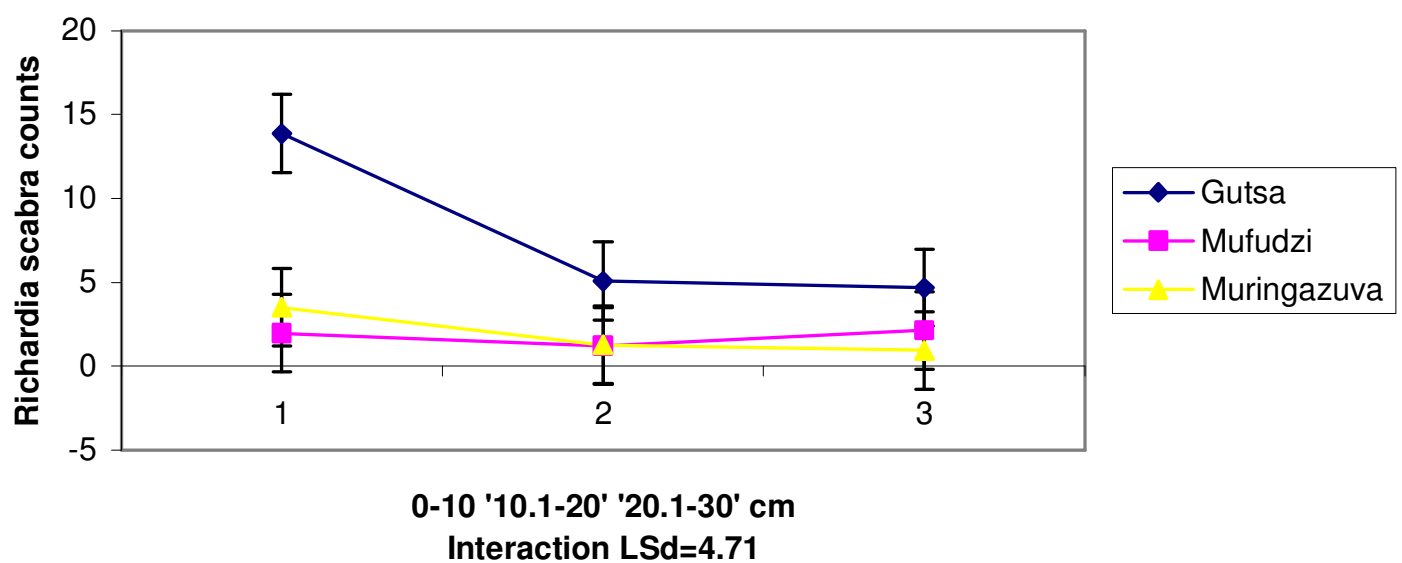

Figure 2. Effects of depth and site on emergence of

Ricardia scabra

The interaction of site and depth on Richardia scabra emergence is seen in the different extent to which Richardia scabra numbers decreased with increasing depth at the soil samples. For Gutsa site, there was a precipitous decrease in Richardia scabra with increase in depth from $0-10 \mathrm{~cm}$ to $10-20 \mathrm{~cm}$. The reduction in Richardia scabra emergence was not as sharp as Mufudzi and Muringazuva (Fig 2).

\section{Urochloa panicoides}

Depth of soil sample $(\mathrm{P}=0.000)$ had highly significant effects on Urochloa panicoides emergence from incubated soil samples. Site $(\mathrm{P}>0.05)$ had no effect on the seed bank size of Urochloa panicoides. There was no interaction between site and depth $(\mathrm{P}>0.05)$. Urochloa panicoides was more abundant in the $0-10 \mathrm{~cm}$ than the $10-20 \mathrm{~cm}$ and 20-30 cm depth (Fig 3). There was a rapid decline in the numbers of Urochloa panicoides as depth was increased from 0-10 cm to $10-20 \mathrm{~cm}$ depth. The $10-20 \mathrm{~cm}$ and 20-30 cm depth had equal numbers of Urochloa panicoides that germinated. 


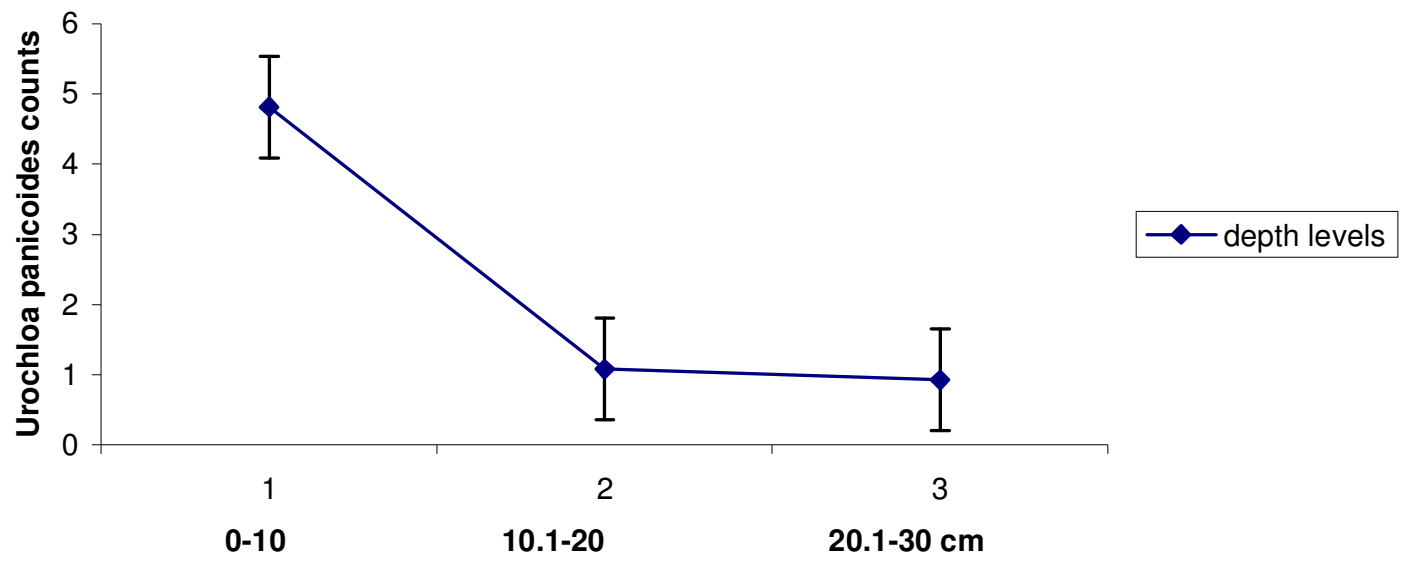

Figure 3. Effect of depth on Urochloa panicoides emergence

\section{Nicandra physaloides}

Site $(\mathrm{P}>0.05)$ had no effect on the seed bank size of Nicandra physaloides. Depth of soil sample $(\mathrm{P}=0.043)$ had significant effects on Nicandra physaloides emergence. There was no interaction between site and depth of soil samples $(\mathrm{P}>0.05)$. High numbers of Nicandra physaloides emerged from the incubated $0-10 \mathrm{~cm}$ of the soil samples. The 10-20 cm and 20-30 $\mathrm{cm}$ had equal numbers of Nicandra physaloides that emerged (Table 2.).

Table 2. Effect of depth on the number of germinable Nicandra physaloides

\begin{tabular}{|c|c|c|c|c|}
\hline Depth (cm) & & & & Means \\
\hline $0-10$ & & & & $1.8510 \mathrm{a}(5.60)$ \\
\hline $10-20$ & & & & $0.8299 \mathrm{~b}(0.40)$ \\
\hline $20-30$ & & & & $1.0322 \mathrm{~b}(1.13)$ \\
\hline & Significance & SED & $\mathrm{LSD}_{0.05}$ & \\
\hline Effect of site & NS & NS & NS & \\
\hline Effect of depth & $\mathrm{P}=0.043$ & 0.41 & 0.84 & \\
\hline Site $\mathrm{x}$ depth interaction & NS & NS & NS & \\
\hline
\end{tabular}

Corchorus olitorus

Site $(\mathrm{P}>0.05)$ and depth of soil sample $(\mathrm{P}>0.05)$ had no effect on the seebank of Corchorus olitorus. There was no interaction between site and depth $(\mathrm{P}>0.05)$.

Cynodon dactylon

Site $(\mathrm{P}=0.006)$ and depth of soil sample $(\mathrm{P}=0.001)$ had highly significant effects on Cynodon dactylon emergence from the incubated soil samples. There was a significant interaction between site and depth of soil sample $(\mathrm{P}=0.044)$. Cynodon dactylon was more abundant at the 0-10 cm depth at Gutsa and Mufudzi than the 10-20 cm and 20-30 $\mathrm{cm}$ depth of the soil samples. The interaction of site and depth on Cynodon dactylon is 
seen in the different extent to which Cynodon dactylon number decreased with increasing depth of the soil samples. For Gutsa and Muringazuva, there was a sharp decrease in Cynodon dactylon numbers with increase in depth from 0-10 cm to 10-20 $\mathrm{cm}$. The decrease in reduction in Cynodon dactylon emergence was not very sharp at Mufudzi (Fig 4.)

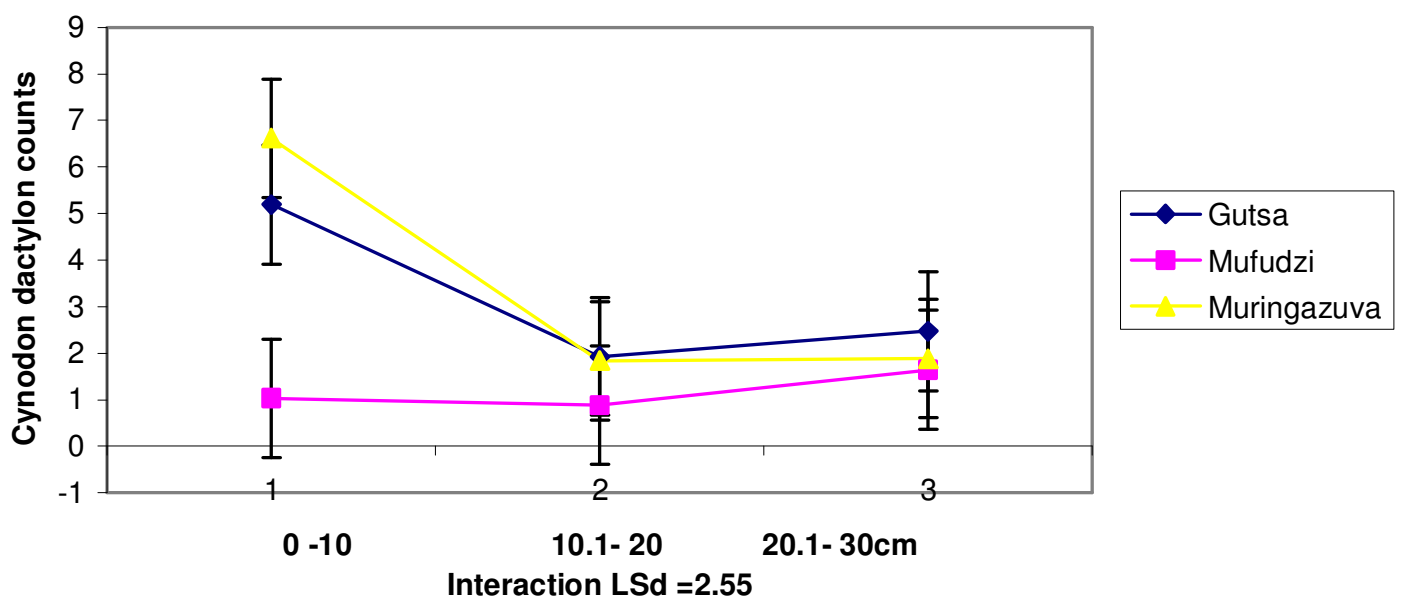

Figure 4. Effect of site and depth on cynodon dactylon emergence

\section{Elusine indica}

Site $(\mathrm{P}>0.05)$ and depth of soil sample $(\mathrm{P}>0.05)$ had no effect on the seed bank of Elusine indica

There was no interaction between site and depth $(\mathrm{P}>0.005)$

\section{Trichodesma zeylanicum}

Depth of soil sample ( $\mathrm{P}>0.05)$ had no significant effect on the emergence of Trichodesma zeylanicum from incubated soil samples. Site $(\mathrm{P}=0.02)$ had significant effects on the seed bank of Trichodesma zeylanicum. Muringazuva had the highest number of Trichodesma zeylanicum that emerged. Gutsa and Muringazuva had equal numbers of germinable Trichodesma zeylanicum (Table 3.). There was no interaction between site and depth of soil sample ( $\mathrm{P}>0.05)$.

Table 3. Effect of site on the number of germinable Trichodesma zeylanicum

\begin{tabular}{|c|c|c|c|}
\hline Site & & & Means \\
\hline Gutsa & & & $0.7071 \mathrm{~b}(0.00)$ \\
\hline Mufudzi & & & $0.9436 \mathrm{~b}(0.60)$ \\
\hline Muringazuva & & & $1.1777 \mathrm{a}(1.33)$ \\
\hline & Significance & SED & $\mathrm{LSD}_{0.05}$ \\
\hline Effect of site & $\mathrm{P}=0.02$ & 0.16 & 0.32 \\
\hline Effect of depth & NS & NS & NS \\
\hline Site $\mathrm{x}$ depth interaction & NS & NS & NS \\
\hline
\end{tabular}




\section{Senna species}

Site $(\mathrm{P}>0.05)$ and depth of soil sample $(\mathrm{P}>0.05)$ had no effect on the seed bank of Senna species. There was no interaction between site and depth of soil sample $(\mathrm{P}>0.05)$ (Appendix 1. 10).

\section{Overall weedbank in all three sites}

The overall weed seed bank in the three sites was made up of nine weed species, with a prevalence of broadleaved weeds. Ranking of weeds was done (Table 4), weed species with the highest mean ranked as one and weed species with lowest mean ranked as nine. Richardia scabra was the dorminant weed species in Gutsa village. Portulaca olerecea was dorminant in Mufudzi and Cynodon dactylon was dorminant in Muringazuva. Some weed species were site specific. Senna species was found in Muringazuva only. Elusine indica was found in Mufudzi village only. Trichodesma zeylanicum was also found in Mufudzi area and Muringazuva and was absent in Gutsa village.

Table 4. Summary of abundance and distribution of weed species in the three sites (transformed data)

\begin{tabular}{l|l|l|l|l|l|l|l}
\hline SPECIES & Gutsa & Rank & Mufudzi & Rank & Muringazuva & Rank & Sign. \\
\hline Portulaca oleracea & 2.51 & 3 & 1.82 & 1 & 1.09 & 6 & $\mathrm{P}=0.169$ \\
\hline Ricardia scabra & 7.88 & 1 & 1.76 & 3 & 1.91 & 3 & $\mathrm{P}=0.000$ \\
\hline Urochloa panicoides & 2.13 & 4 & 1.79 & 2 & 2.90 & 2 & $\mathrm{P}=0.41$ \\
\hline $\begin{array}{l}\text { Nicandra } \\
\text { physaloides }\end{array}$ & 1.13 & 5 & 0.78 & 7 & 1.66 & 4 & $\mathrm{P}=0.203$ \\
\hline Cynodon dacyton & 3.2 & 2 & 1.18 & 4 & 3.45 & 1 & $\mathrm{P}=0.006$ \\
\hline Eleusine indica & 0.71 & 7 & 0.88 & 8 & 0.71 & 9 & $\mathrm{P}=0.248$ \\
\hline $\begin{array}{l}\text { Trichodesma } \\
\text { zeylanicum }\end{array}$ & 0.71 & 7 & 0.94 & 5 & 1.18 & 5 & $\mathrm{P}=0.02$ \\
\hline Senna species & 0.71 & 7 & 0.71 & 9 & 0.93 & 8 & $\mathrm{P}=0.173$ \\
\hline Corchorus olitorus & 0.94 & 6 & 0.78 & 7 & 1.00 & 7 & $\mathrm{P}=0.437$ \\
\hline
\end{tabular}

Value 0.71 means the weed was absent in the original data.

\section{Discussion}

In all farmers' fields, about $59.3 \%$ of the total weed seed bank was concentrated in the upper $0-10 \mathrm{~cm}$ of the soil. Such a large surface seed stock is attributed to the considerable seed rain that occurred during the recent crop cycle because of inadequate weed control. Farmers have a tendency of not weeding late weeds. These late weeds are responsible for enriching the seedbank. Cardina et al., 1992 found that with control of these late weeds and good weed control management throughout the season, the soil seed bank can actually be depleted to result in reduced weed problems in the subsequent years with consequent savings of time and weed control costs. About $19.3 \%$ of the total weed seed bank was concentrated in the $10-20 \mathrm{~cm}$ and the other $21.4 \%$ was concentrated in the $20-30 \mathrm{~cm}$ of the soil. Cardina et al., 1992 also found that the top 0-5 $\mathrm{cm}$ of the soil had the highest numbers of the total weed seeds. An equal distribution of weed seeds in the 10- $20 \mathrm{~cm}$ and 20-30 cm support work done earlier on by Yenish et al (1992). Weed seed depth distribution besides being affected by tillage is also affected by soil type with those soil likely to crack (silty clay loam) causing freshly produced seed to be deposited deeper than the non-cracking soils (Cardina et al., 1992). Also of 
importance some weed seeds, which are buried deeply by the plough rot or are preyed by micro-organisms hence viability is lost, or have acquired dormancy which required a long period of time to germinate thus fewer seed numbers in the $10-20 \mathrm{~cm}$, and $20-30 \mathrm{~cm}$ depth levels.

Seed bank size was highest in a field with a period of cultivation greater than 20 years. Weeds among other characteristics are known to proliferate quickly in soils that have been disturbed for a long time and are continuously being disturbed. For example Richardia scabra is known to favour exhausted soils with a low $\mathrm{pH}$. The differences in the size of the seed-bank among the three farmer's fields can also attributed to by differences in fields location, cropping history, edaphic characteristics such as moisture holding capacity and past weed control practices and tillage, land preparation methods.

\section{Conclusions}

The 0-10 cm depth level contains higher weed seeds than the $10.1-20$ and $20.1-30 \mathrm{~cm}$ depth levels. Fields, which have been cultivated for a long period of time, tend to have a larger seed bank than fields, which have been opened recently.

\section{REFERENCES}

[1] Akobundu, I. O. (1987): Weed Science in the Tropics - John Wiley and Sons.

[2] Altieri, M. A., Liebman, M. (1988): Weed Management in Agroecosystems; Ecological Approaches. - CRC Press, Inc, Raton, Florida.

[3] Barralis, G., Chadoeuf, R. (1987): Potential semencier des terres arables. - Weed Research 27: 417-24.

[4] Cardinal, J., Harrison, K. (1991): Long term tillage effects on seed banks in three Ohio soils. Weed Science 39: 186.

[5] Clements, D.R., Weise, S.F., Swanton, C.J. (1994): Intergrated weed management and weed species diversity. - Phytoprotection 75: 1-18.

[6] Cotton Handbook (1985): Commercial Cotton Growers' Association of Zimbabwe. Harare.

[7] Department of Agricultural Technical Extension Services, Mashonaland Central (1999): Background on Agriculture in Muzarabani and Constrants. - Ministry of Lands and Rural Resettlement Zimbabwe.

[8] Forcella, F. (1992) Prediction of weed seedling densities from buried seed reserves. Weed Research 32: 29-38

[9] Janiya, J.D., Moody, K. (1989): Weed populations in transplanted and wet seeded rice as affected by weed control methods. - Tropical Pest Management 35: 8-11.

[10] Yenish, J.P., Doll, J.D., Buhler, D.D. (1992): Effects of tillage on vertical distribution and viability of weed seed in soil. - Weed Science 40: 429-433.

[11] Zimdahl, R.L., Moody, K., Lubigan, R.T., Castin, E.M. (1988): Patterns of weed emergence in tropical soils. - Weed Science 36: 603-608. 